UDC 338.14

DOI: $10.15587 / 2312-8372.2017 .113218$

\section{Mashchenko M., Klimenko D., Dykan 0.}

\title{
OPTIMIZATION OF EXPENDITURES ON ENVIRONMENTAL ACTIONS IN UKRAINE
}

Представлено аналіз витрат на охорону та раціональне використання природних ресурсів за напрямами природоохоронних витрат держави в динаміці за методом експертних оцінок. Визначено напрями оптимізації витрат на ращіональне використання природних ресурсів України для першочергового додаткового фінансування природоохоронної діяльності держави. Найважливішим результатом використання даного методичного підходу є прогнозування соціально-еколого-економічного розвитку України.

Ключові слова: напрями природоохоронних витрат держави, природні ресурси, екологія, природоохоронні витрати, рачіональне природокористування, економіка.

\section{Introduction}

At the present stage of development there is a constant improvement of technics and technology due to scientific and technical progress, which leads to economic growth. The latter is one of the main goals of any state. Economic growth is an increase in the volume of national production. As a consequence, all this leads to an increase in the use of natural resources, namely, mineral-raw materials, agro-climatic, biotic, recreational, etc.

The use of natural resources is carried out to meet the needs of mankind for a long time and is the only source of human existence as a person and human society as a whole. At the present stage, a special role in society is played by rational nature management, which consists in using natural resources in such way as to ensure harmony between the interaction between society and the environment and, as a result, sustainable economic development. Along with the problem of economic growth, society must overcome the ecological crisis. The industrial consumption of natural resources is in conflict with the natural capacity for self-recovery. Thus, environmental protection the process of protecting, restoring and reproducing the natural resource potential of the economy - should be the main component of economic activity.

Rational management in conjunction with environmental management aims to avoid possible harmful effects of human activities and to ensure high productivity and economy of resource use.

For Ukraine, the perfect embodiment of the concept of sustainable development in the life of the country, among many problems, requires defining ways to rationalize the relationship between society and nature. One of the most important and complex strategic tasks at this stage is the country's transition towards the development of an ecologically safe national economy [1-3].

An effective mechanism for the use of nature is impossible without the provision of environmental and economic management, one of the components of which is to optimize the expenditures on rational use of environmental actions of the state. Taking into account the unshakable need for rational use of natural resources and limited funding for environmental activities in the state, it is necessary to create a methodological approach to the rational use of Ukraine's natural resources. The beginning of such methodical approach is the optimization of environmental expenditures, which determines the relevance of this article.

\section{The object of research and its technological audit}

The object of research is direction of environmental expenditures on the state. Let's clarify the fact that directions of nature protection expenditures are identified in this study with the directions of expenditures on the rational use of natural resources. The peculiarity of determining the object of research is the selected conditions, namely the order of additional funding for the nature protection activities of the state. This feature is important primarily for Ukraine, but the usefulness of the approach for use in other countries seems to be beyond doubt.

Selected research conditions do not allow to make excellent use of foreign experience, since scientists of many foreign countries mainly consider certain areas of environmental protection.

Disadvantages of the current state of the object of the study are that, given the possibility of additional financing for environmental actions, there is no clear optimization of these expenditures. Therefore, it is necessary to define an approach for searching for the most important areas of expenditures on the rational use of natural resources in conditions that are very likely to be compiled in Ukraine.

\section{The aim and objectives of research}

This research is aimed to determine the directions of optimization of expenditures on the protection and rational use of natural resources of Ukraine for priority additional financing of the state's environmental activities.

To achieve this aim, the following objectives are accomplished:

1. To analyze the expenditures on protecting and rationally using natural resources in the direction of the state's environmental actions in dynamics. 
2. To determine the place of the analysis of expenditures on protection and rational use of natural resources in the directions of the state's environmental actions in the methodical approach to the rational use of Ukraine's natural resources that is being developed.

In the near future, the issue of identifying priority areas for environmental protection of the state becomes even more important due to the active development of the process of European integration in Ukraine. In addition, the possibility of additional funding from the state budget also requires a clear definition of the most important areas of environmental expenditures.

\section{Research of existing solutions of the problem}

Problems of ecology, including environmental protection and rational use of natural resources, are widely studied by domestic and foreign scientists. Foreign experience in formation of a sustainable development economy, where environmental, social and economic problems are closely linked, in general is very important for Ukraine. Some foreign and domestic scientists are considering certain areas of environmental actions of the state and solve energy problems for a sustainable future [4], problems of waste processing [5] or purity of water resources [6]. Very interesting are the studies comparing various regulatory instruments of state environmental policy in the US and Europe and the expenditures on these, and are looking for the most rational and effective tools and methods [7]. Such experience makes it possible to evaluate also the effectiveness of various instruments that use in the environmental actions of a country with a developed economy. Significant contribution of scientists from Germany [8, 9], who analyzed the impact of thematic literature on the ecological economy as a science and practice, and found further development of research on environmental actions in a more applied and empirical direction. Studies of the interdependence between ecological systems and man, in particular, ecosystem services and the welfare of the population, are of great importance for environmental science and sustainable development of countries [10, 11]. Domestic scientists make a significant contribution to solving the problem of rational nature management, including from fundamental issues of monitoring air, water, soil, waste, biodiversity, as well as state management of quality and environmental monitoring, environmental monitoring, standardization and metrological control of pollution control the environment [12].

So, many scientists of the world are engaged in solving the problem of rational use of natural resources and in general, and in particular; covering issues of environmental protection expenditures and state environmental monitoring, conduct interesting research on this topic. The availability of applied research for the definition of areas to optimize the expenditures on environmental protection in the face of limited additional financing of the state us insufficient. In addition, with all the standards, norms and acts concerning environmental actions, Ukraine [12], the state needs an easy-to-use methodical approach to the rational use of the country's natural resources. Creation of such methodical approach is advisable to begin with an analysis of the state's expenditures on environmental actions and determining the most optimal directions of environmental expenditures.

\section{Methods of research}

5.1. Investigation of the structure of expenditures on protection and rational use of natural resources in the dynamics. The authors of the article conduct a long-term study on the process of reproduction of natural resources in Ukraine.

Thus, in the course of the research, an analysis is made of the state's expenditures on certain environmental actions in dynamics.

The main directions of environmental expenditures on Ukraine are nine selected areas, including:

- protection of atmospheric air and problems of cli-

mate change;

- sewage treatment;

- waste management;

- protection and rehabilitation of soil, underground and surface water;

- reduction of noise and vibration effects;

- conservation of biodiversity and habitat;

- radiation safety;

- scientific research work of nature protection direction;

- other areas of environmental protection.

In the opinion of the authors, these areas sufficiently fully reflect the structure of expenditures on the protection and rational use of natural resources according to the mission of the Ministry of Ecology and Natural Resources of Ukraine [13].

At the moment, the dynamics of Ukraine's expenditures on environmental activities tracked for two years - 2014 and 2015. At the same time used the official figures, which are in direct access [14, 15].

For ease of analysis, security expenditures and the rational use of natural resources in areas of environmental expenditures represented Ukraine in the form of threedimensional diagrams and are presented in Fig. 1, 2.

As can be seen from Fig. 1, state carries out the greatest expenditures on wastewater treatment; waste management; radiation safety; protection of atmospheric air and problems of climate change.

Lowest expenditures - to reduce noise and vibration effects; conservation of biodiversity and habitat; scientific research work of nature protection direction; other areas of environmental protection.

As can be seen from the figures, the structure of expenditures on the protection and rational use of natural resources has changed insignificantly in two years. For convenience, the data are tabulated (Table 1).

As can be seen from the table, more or less significant is the increase in expenditures on the direction of waste management by $2.3 \%$.

Such minor changes nevertheless determine the distribution of the general budget for the protection and rational use of natural resources, especially given the fact that the development of European neighboring countries pays much attention to environmental issues, including clean air. It should be recalled that European countries have repeatedly pointed out to Ukraine the need to increase the expenditures on the atmosphere protection. 


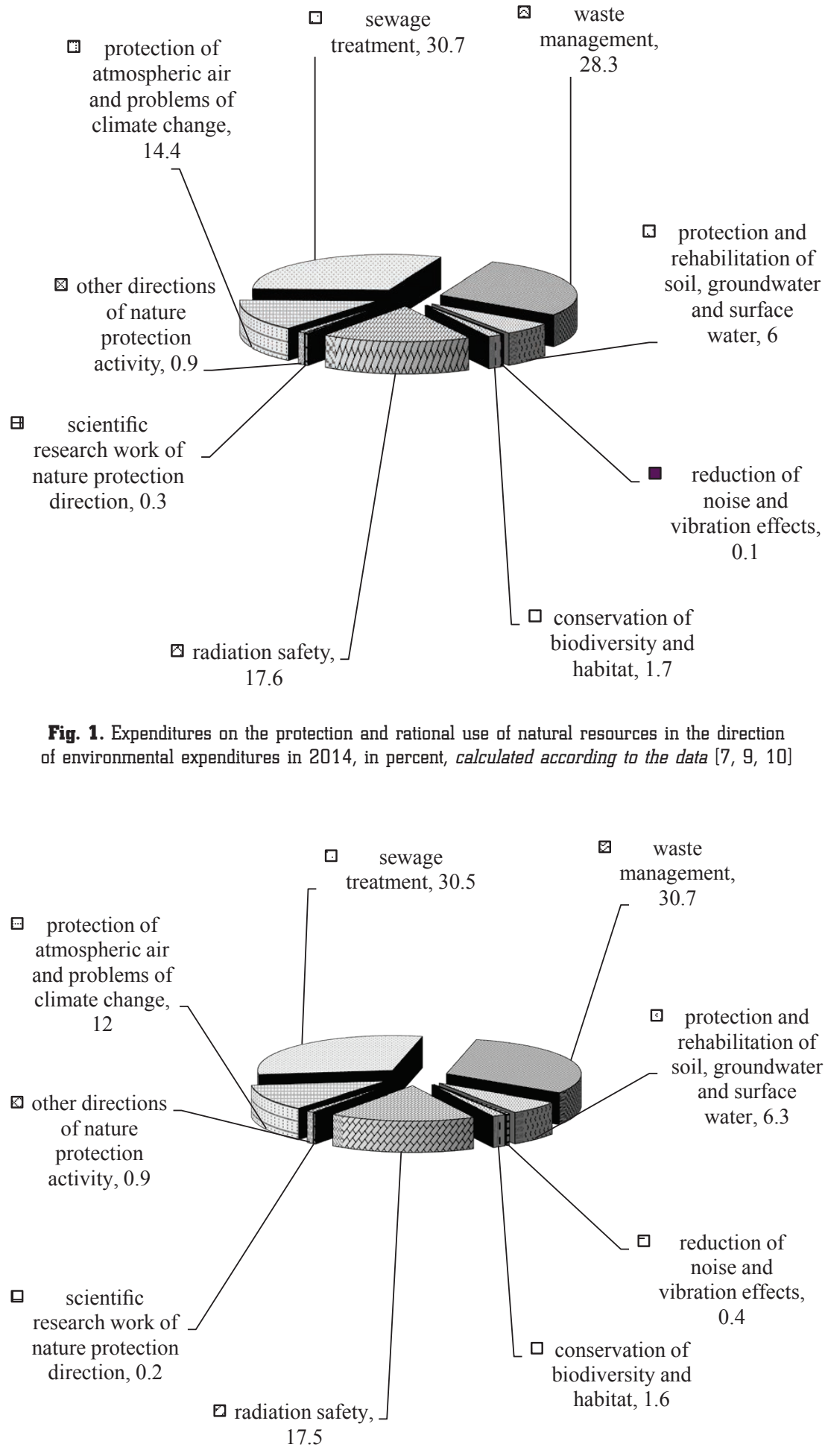

Fig. 2. Expenditures on the protection and rational use of natural resources in the direction of environmental expenditures in 2015, in percent, calculated according to the data $[7,9,10]$

Table 1

Dynamics of the structure of expenditures on the protection and rational use of natural resources for 2014 and 2015, in percent

\begin{tabular}{|c|c|c|c|c|}
\hline No. & $\begin{array}{l}\text { Direction of } \\
\text { environmental } \\
\text { expenditures }\end{array}$ & $\begin{array}{c}2014 \\
(\%)\end{array}$ & $\begin{array}{c}2015 \\
(\%)\end{array}$ & $\begin{array}{c}\text { Changes } \\
(\%)\end{array}$ \\
\hline 1 & $\begin{array}{l}\text { protection of } \\
\text { atmospheric air and } \\
\text { problems of climate } \\
\text { change }\end{array}$ & 14.4 & 12 & -2.4 \\
\hline 2 & sewage treatment & 30.7 & 30.5 & -0.2 \\
\hline 3 & waste management & 28.3 & 30.6 & +2.3 \\
\hline 4 & $\begin{array}{l}\text { protection and re- } \\
\text { habilitation of soil, } \\
\text { groundwater and } \\
\text { surface water }\end{array}$ & 6 & 6.3 & +0.2 \\
\hline 5 & $\begin{array}{l}\text { reduction of noise } \\
\text { and vibration effects }\end{array}$ & 0.1 & 0.4 & +0.3 \\
\hline 6 & $\begin{array}{l}\text { conservation of } \\
\text { biodiversity and } \\
\text { habitat }\end{array}$ & 1.7 & 1.6 & -0.1 \\
\hline 7 & $\begin{array}{l}\text { scientific research } \\
\text { work of nature } \\
\text { protection direction }\end{array}$ & 17.6 & 17.5 & -0.1 \\
\hline 8 & $\begin{array}{l}\text { other directions of } \\
\text { nature protection } \\
\text { activity }\end{array}$ & 0.3 & 0.2 & -0.1 \\
\hline 9 & $\begin{array}{l}\text { protection of } \\
\text { atmospheric air and } \\
\text { problems of climate } \\
\text { change }\end{array}$ & 0.9 & 0.9 & - \\
\hline & Total & 100 & 100 & - \\
\hline
\end{tabular}

5.2. Use of peer review method to determine priority areas for environmental expenditures. To determine the priority directions of environmental expenditures and to create their optimal structure in the process of research, the method of expert assessments is applied. This method includes the following steps:

- formation of a matrix of ranks; - calculation of the coefficient of multiple rank correlation and the criterion of randomness of results; - analysis of the obtained results.

The first stage - formation of a matrix of ranks - is of great importance for obtaining reliable results, and is also the most time-consuming.

Formation of the rank matrix provides the following stages of research:

It seems that a reduction in the expenditures on protecting the air, wastewater treatment, protection, rehabilitation of soil, underground and surface water is primarily a result of inadequate financing of environmental actions.

So, it is necessary to define priority directions for priority additional financing of expenditures on environmental activities of the state.
- development of a questionnaire for the collection of information on the directions of environmental activities;

- definition of experts, conscious in a particular field of science and practice;

- conducting an expert survey;

- systematization of the results obtained for the further stages. 
Questioning is a fairly common and simple way of obtaining information. In this study, the questionnaire is developed in accordance with the purpose of the analysis: the questions of the questionnaire cover a rather wide range of directions of the state's environmental activities. These directions completely repeat the directions of nature protection expenditures, formed by the Ministry of Ecology and Natural Resources of Ukraine [13]. The examination questionnaire is constructed in an open manner in tabular form. The main goal is obtaining information on the rank of a particular area of environmental protection. The questionnaire used for the examination is given in Table 2. Anonymity of the questionnaire seems to be an essential requirement, which increases the likelihood of transparent answers.

Table 2

An application form for collecting information on the directions of environmental protection activities

\begin{tabular}{|c|l|c|c|c|}
\hline \multicolumn{3}{|l|}{$\begin{array}{l}\text { Near colleague! Please note the rank of the environmental direction about the } \\
\text { need to finance the expenditures on protection and rationally use of natural } \\
\text { resources. } 1 \text { - the most important, } 3 \text { - the least important }\end{array}$} \\
\hline No. & Direction of environmental expenditures & 1 & 2 & 3 \\
\hline 1 & $\begin{array}{l}\text { protection of atmospheric air and problems of climate } \\
\text { change }\end{array}$ & & \\
\hline 2 & sewage treatment & & & \\
\hline 3 & waste management & & & \\
\hline 4 & $\begin{array}{l}\text { protection and rehabilitation of soil, groundwater and } \\
\text { surface water }\end{array}$ & & \\
\hline 5 & reduction of noise and vibration effects & & & \\
\hline 6 & conservation of biodiversity and habitat & & & \\
\hline 7 & scientific research work of nature protection direction & & & \\
\hline 8 & other directions of nature protection activity & & & \\
\hline 9 & $\begin{array}{l}\text { protection of atmospheric air and problems of climate } \\
\text { change }\end{array}$ & & \\
\hline
\end{tabular}

When forming a matrix of ranks, experts provide solutions to complex problems and the construction of models. The group of experts should include those professionals who have experience in this field of science and practice. In this study, experts were made by experts of a wide range, among which there are scientists and practitioners. The selection of experts was carried out on the basis of:

- the reputation of experts among specialists;

- the experience of successful predictions in this field of knowledge and the like.

When solving the task of forming an expert group, a workable group of ten experts was found and stabilized.

The group was formed from specialists of various institutions of the Kharkov region, namely:

- Kharkov Zoo (1 expert);

- National nature park «Dvorichanskyi» (2 experts); - V. N. Karazin Kharkiv National University - biological faculties (1 expert), geological-geographical (2 experts), ecological (2 experts);

- State Ecological Inspectorate of Kharkiv (1 expert); - ecological group «Pechenegi» (1 expert).

The obtained group of experts can be considered a general set of specialists competent in the field of the forecasted problem.
The survey of experts in the study was conducted from October to November 2016.

Experts ranked each direction of nature protection activities of the state in terms of the degree of necessity of its application. In this case, the priority direction is assigned the value «1». If the direction is less priority, the value assigned the value $\ll 2 »$, or $\ll 3 »$.

The first stage of the study ends with the systematization of the obtained results. For this purpose, based on the analysis of the examination questionnaires, a matrix of the ranks of the environmental activities was formed, including expert opinions. The matrix of ranks is presented in Table 3. In this case, the factors correspond to the number of the direction of environmental expenditures according to Table 1 .

Matrix of ranks of nature protection activity directions

\begin{tabular}{|c|c|c|c|c|c|c|c|c|c|c|}
\hline \multirow{2}{*}{ Directions } & \multicolumn{10}{|c|}{ Experts } \\
\cline { 2 - 12 } & 1 & 2 & 3 & 4 & 5 & 6 & 7 & 8 & 9 & 10 \\
\hline 1 & 1 & 1 & 1 & 2 & 1 & 1 & 1 & 1 & 1 & 1 \\
\hline 2 & 2 & 1 & 1 & 1 & 2 & 1 & 1 & 1 & 1 & 1 \\
\hline 3 & 1 & 1 & 1 & 1 & 1 & 2 & 2 & 2 & 1 & 1 \\
\hline 4 & 2 & 2 & 2 & 1 & 1 & 2 & 2 & 1 & 1 & 3 \\
\hline 5 & 2 & 3 & 2 & 3 & 2 & 2 & 1 & 2 & 2 & 2 \\
\hline 6 & 1 & 2 & 3 & 2 & 3 & 3 & 2 & 2 & 2 & 2 \\
\hline 7 & 1 & 1 & 2 & 1 & 1 & 1 & 2 & 2 & 2 & 1 \\
\hline 8 & 2 & 2 & 2 & 2 & 3 & 3 & 2 & 2 & 3 & 3 \\
\hline 9 & 2 & 2 & 2 & 3 & 3 & 1 & 1 & 3 & 3 & 3 \\
\hline
\end{tabular}

As can be seen from the table, the interviewed experts differed very unequally from the priority of expenditures on the protection and rational use of natural resources. Further systematization provides for averaging the obtained results and deducing the ranks of the directions of environmental protection.

Thus, as a result of the first stage of the study, the results shown in Table 4 are obtained.

Table 4

Table of the results of the first stage of determining priority areas of environmental expenditures and the creation of their optimal structure by the method of expert assessments

\begin{tabular}{|c|c|c|c|}
\hline Directions & Sum of ranks & Average rank & Direction rank \\
\hline 1 & 11 & 1.1 & 1 \\
\hline 2 & 12 & 1.2 & 2 \\
\hline 3 & 13 & 1.3 & 3 \\
\hline 4 & 17 & 1.7 & 5 \\
\hline 5 & 21 & 2.1 & 6 \\
\hline 6 & 22 & 2.2 & 7 \\
\hline 7 & 14 & 1.4 & 4 \\
\hline 8 & 24 & 2.4 & 9 \\
\hline 9 & 23 & 2.3 & 8 \\
\hline
\end{tabular}

The second stage of the study is the calculation of the multiple rank correlation coefficient and the criterion of randomness of results. It is necessary to determine the 
consistency of expert opinions and the belief that the degree of coherence is not accidental.

Therefore, to assess the consistency of expert opinions, the multiple rank correlation coefficient $(W)$ must be calculated from the formula [16]:

$$
W=\frac{12 \cdot S}{m^{2} \cdot\left(n^{3}-n\right)},
$$

where $S$ - deviation of the sum of squares of ranks from the average squares of ranks; $m$ - number of experts; $n$ - number of factors.

From the formula it is clear that in this study $m$ is equal to 10 (the number of experts), and $n$ is equal to 9 (the number of directions of nature protection activity). The deviation of the sum of the squares of the ranks on the average squares of ranks is calculated from the data of Table 4 and is equal to 4920 .

Concordance coefficient of expert opinions who took part in determining the directions of environmental activities of the state is:

$$
W=\frac{12 \cdot 4920}{10^{2} \cdot\left(9^{3}-9\right)}=0.82184 .
$$

It is known that the closer the concordance coefficient to 1 , the stronger the dependence between the quantities. In this study, the coefficient is 0.82184 . Therefore, the degree of agreement between the experts' opinions is quite high.

For test of the importance of the obtained multiple rank correlation coefficient, the criterion $\chi^{2}$ is used, which obeys the $\chi^{2}$ - distribution with the number of degrees of freedom $f=n-1$ :

$$
\chi^{2}=m \cdot(n-1) \cdot W
$$

The significance criterion of the obtained multiple rank correlation coefficient in this study is:

$$
\chi^{2}=10 \cdot(9-1) \cdot 0.82=90.44
$$

According to the table of critical values of the Pearson test, $\chi^{2}$ for $5 \%$ of the significance level is 70.1 . Since the calculated $\chi^{2}$ is more than tabular $\chi^{2}$, with a probability of 0.95 , it can be argued that consistency in the opinions of experts is not accidental.

So, the result of the second stage of the study is the definition that the expert opinion is consistent and the consistency is not accidental.

The final stage of the study is analysis of the obtained results.

\section{Research results}

On the basis of the calculations, those environmental directions that have the maximum rank about the need to finance the expenditures on protecting and rational use of natural resources in the relevant analysis group are selected. The received justified list of directions of nature protection expenditures by priority of expenditures is given in Table 5 .

Thus, for today the priority directions for environmental protection of the state should be the protection of atmospheric air and the problems of climate change, sewage treatment and waste management.
It should be noted that all areas of environmental protection in Ukraine require significant costs. But if there is an opportunity for the state to increase financing for environmental expenditures, it will be rational to send additional funds according to certain priorities.

Table 5

Table of priorities for environmental expenditures

\begin{tabular}{|c|l|}
\hline $\begin{array}{c}\text { Priority of } \\
\text { direction }\end{array}$ & \multicolumn{1}{c|}{ Direction of environmental expenditures } \\
\hline 1 & Protection of atmospheric air and problems of climate change \\
\hline 2 & Sewage treatment \\
\hline 3 & Waste management \\
\hline 4 & $\begin{array}{l}\text { Protection and rehabilitation of soil, groundwater and surface } \\
\text { water }\end{array}$ \\
\hline 5 & Beduction of noise and vibration effects \\
\hline 6 & Conservation of biodiversity and habitat \\
\hline 7 & Scientific research work of nature protection direction \\
\hline 8 & Dther directions of nature protection activity \\
\hline 9 & Protection of atmospheric air and problems of climate change \\
\hline
\end{tabular}

The effectiveness of the implementation of the development of priority areas for environmental protection of the state through the method of expert assessments requires a special definition and has a promising place among longterm research on the process of reproduction of natural resources in Ukraine carried out by the authors.

\section{SWOT analysis of research results}

Strengths. Analysis of the expenditures on protection and rational use of natural resources in Ukraine in terms of environmental expenditures to optimize them is a composite development of a methodical approach to the rational use of natural resources of Ukraine. Development of such methodical approach is carried out by the authors in the framework of a long-term study on the process of reproduction of natural resources in Ukraine.

The development of a methodical approach involves several important steps. At the moment, there are five such stages, namely:

- monitoring of the state of natural resources of Ukraine; - analysis of expenditures on protection and rational use of natural resources in the direction of environmental expenditures in the dynamics;

- development of priority directions for environmental activities of the state using the method of expert assessments;

- determination of the implementation effectiveness of the development of priority areas for environmental activities of the state;

- forecasting of socio-ecological and economic development of Ukraine. The fifth stage of the presented methodical approach is of significant importance for the modern general development of Ukraine.

Weaknesses. Optimization of expenditures of environmental actions should be continuous and based on a thorough and regular analysis of the process. As a consequence, this requires some material investment.

Opportunities. The development of the national economy requires a further increase in expenditures on all 
areas of the state's environmental activities, the process of optimizing expenditures is constant and continuous. Therefore, the problem of protection and rational use of natural resources, including an analysis of optimization of environmental protection expenditures, should be accompanied by in-depth scientific research of an applied nature. Thus, the development of a methodical approach to the rational use of natural resources of Ukraine, one of the most important results of which is the forecasting of the socio-ecological and economic development of Ukraine, requires the development. The stage of forecasting the methodological approach presented in the general view is of great importance for the modern and further development of Ukraine. Forecasting should be continuous and based on close, reliable and regular analysis. Therefore, scientific research is of a long-term nature and will be carefully conducted by the authors. Also, the need to replenish the country's budget by improving the mechanism of paid nature management requires scientific research and finds its place in an integrated methodology for the rational use of natural resources that is the further aim of research.

Threats. The continuous process of reforming the economy raises the issue of changing the main elements of the economic mechanism of nature management and environmental protection, such as: environmental taxes; payment for the use of natural resources; compensation of losses from violation of environmental protection legislation. This can lead to the need to change the course of research somewhat.

\section{Conclusions}

As a research results, the following results are obtained.

1. The most significant directions of nature protection actions of the state are determined from the point of view of the priority of financing, namely: at the present stage in Ukraine priority directions for additional financing of nature protection activity of the state are several directions - this is protection of atmospheric air and problems of climate change, water treatment and waste management policy.

2. The developed methodological approach to environmental protection is shown, one of the most important results of which is the forecasting of the socio-ecological and economic development of Ukraine.

The place of the analysis of expenditures on the protection and rational use of natural resources in the directions of the state's environmental actions in the methodical approach to the rational use of natural resources of Ukraine is determined, which is being developed.

\section{References}

1. Baldzhy, M. D. Orhanizatsiino-ekonomichni zasady kompleksnoho pryrodokorystuvannia na rehionalnomu rivni [Text]: Monograph / M. D. Baldzhy. - Odesa: Atlant, 2010. - 500 p.

2. Honcharuk, L. Ya. Sotsializatsiia ekonomichnykh system: problemy pryrody, typolohizatsii ta metrolohichnoho analizu [Text] / L. Ya. Honcharuk, H. I. Bashnianyn; ed. by H. I. Bashnianyn // Ekonomichni systemy. - Lviv: Lviv Commercial Academy, 2006. - Vol. 1. - P. 100-116.

3. Koppel, J. Germany's Energiewende [Text] / J. Koppel // Innovation Society Today. - Fachmedien, Wiesbaden: Springer, 2017. - P. 273-293. doi:10.1007/978-3-658-19269-3 13

4. Armstrong, F. Energy ... beyond oil [Text] / F. Armstrong, K. Blundell. - Oxford: Oxford Univ. Press, 2007. - 229 p.

5. Gubanova, E. R. Mehanizm ekonomiko-ekologicheskogo stimulirovaniia ispol'zovaniia vtorichnyh resursov [Text]: Monograph / E. R. Gubanova. - Odessa: «TES», 2009. - 280 p.
6. Yevtushenko, M. Yu. Biolohichni resursy hidrosfery [Text]: Monograph / M. Yu. Yevtushenko, Yu. A. Hliebova. - Kyiv: Ukrainskyi fitosotsiolohichnyi tsentr, 2013. - 179 p.

7. Harrington, W. Choosing Environmental Policy: Comparing Instruments and Outcomes in the United States and Europe [Text] / W. Harrington, R. Morgenstern, T. Sterner. - Taylor \& Francis, 2004. - 296 p. doi:10.4324/9781936331468

8. Hoepner, A. G. F. Environmental and ecological economics in the 21st century: An age adjusted citation analysis of the influential articles, journals, authors and institutions [Text] / A. G. F. Hoepner, B. Kant, B. Scholtens, P.-S. Yu // Ecological Economics. 2012. - Vol. 77. - P. 193-206. doi:10.1016/j.ecolecon.2012.03.002

9. Hoepner, A. G. F. Is the journal Ecological Economics really in itself a poor and misleading guide to what ecological economics is about? A reply to «Influencing the perception of what and who is important in ecological economics» [Text] / A. G. F. Hoepner, B. Kant, B. Scholtens, P.-S. Yu // Ecological Economics. - 2013. Vol. 89. - P. 174-176. doi:10.1016/j.ecolecon.2013.03.001

10. Daw, T. M. Elasticity in ecosystem services: exploring the variable relationship between ecosystems and human well-being [Text] / T. M. Daw, C. Hicks, K. Brown, T. Chaigneau, F. Januchowski-Hartley, W. Cheung, S. Rosendo, B. Crona, S. Coulthard, C. Sandbrook, C. Perry, S. Bandeira, N. A. Muthiga, B. SchulteHerbrüggen, J. Bosire, T. R. McClanahan // Ecology and Society. 2016. - Vol. 21, No. 2. - P. 11. doi:10.5751/es-08173-210211

11. Villamagna, A. Adapting human well-being frameworks for ecosystem service assessments across diverse landscapes [Text] / A. Villamagna, C. Giesecke // Ecology and Society. - 2014. Vol. 19, No. 1. - P. 11. doi:10.5751/es-06173-19011

12. Zerkalov, D. V. Ekolohichna bezpeka ta okhorona dovkillia [Text]: Monograph / D. V. Zerkalov. - Kyiv: Osnova, 2012. - 514 p.

13. Development strategy [Electronic resource] // Ministry of Environment and Natural Resources Ukraine. - 30 March 2017. Available at: \www/URL: https://menr.gov.ua/content/misiyata-strategiya.html

14. Natsionalna dopovid pro stan navkolyshnoho pryrodnoho seredovyshcha v Ukraini u 2014 rotsi [Electronic resource]. - Kyiv: Ministry of Environment and Natural Resources Ukraine, FOP Hrin D. S., 2016. - 350 p. - Available at: \www/URL: http:// old.menr.gov.ua/docs/activity-dopovidi/NacDopovid2014.pdf

15. Stan ekonomiky Ukrainy. Analiz [Electronic resource] / Press service of the Ministry of Finance // Government portal. 02.04.2014. - Available at: \www/URL: http://www.kmu.gov.ua/ control/uk/publish/article?art_id $=247169548$

16. Maliarets, L. M. Ekonomiko-matematychni metody ta modeli [Text]: Handbook / L. M. Maliarets. - Kharkiv: KhNEU n. a. S. Kuznets, 2014. -412 p.

\section{ОПТИМИЗАЦИЯ РАСХОДОВ НА ПРИРОДООХРАННЫЕ ДЕЙСТВИЯ} УКРАИНЫ

Представлен анализ расходов на охрану и рациональное использование природных ресурсов по направлениям природоохранных государственных расходов в динамике по методу экспертных оценок. Определены направления оптимизации расходов на рациональное использование природных ресурсов Украины для первоочередного дополнительного финансирования природоохранной деятельности страны. Важнейший результат использования данного методического подхода - прогнозирование социально-еколого-экономического развития Украины.

ключевые слова: направления природоохранных расходов, природные ресурсы, экология, природоохранные затраты, рациональное природопользование, экономика.

Mashchenko Maryna, PhD, Associate Professor, Department of Political Economy, Simon Kuznets Kharkiv National University of Economics, Ukraine,e-mail: Maryna.Mashchenko@hneu.net, ORCID: http://orcid.org/0000-0002-8863-6040

Klimenko Olena, PhD, Associate Professor, Department of Political Economy, Simon Kuznets Kharkiv National University of Economics, Ukraine, e-mail: Olena.Klimenko@hneu.net, ORCID: http://orcid.org/ 0000-0002-2573-9333

Dykan Olena, Doctor of Economic Sciences, Professor, Department of Management and Administration, Ukrainian State University of Railway Transport, Kharkiv, Ukraine, ORCID: http://orcid.org/00000001-9469-6528 